\title{
ODPOWIEDZIALNOŚĆ KARNA A BRAK ZAGROŻENIA DLA DOBRA PRAWNEGO PRZY PRZESTĘPSTWACH ABSTRAKCYJNEGO NARAŻENIA NA NIEBEZPIECZEŃSTWO
}

\begin{abstract}
Streszczenie. Na niniejszy tekst składają się rozważania o zakresie odpowiedzialności karnej w ramach przestępstw abstrakcyjnego narażenia na niebezpieczeństwo. Celem przeprowadzonej analizy jest próba zarysowania możliwości uzasadnienia ograniczenia odpowiedzialności karnej za wskazany typ przestępstw przez uwzględnienie tzw. przeciwdowodu braku zagrożenia. Rozważania skupiły się na relacji przeciwdowodu z konstrukcją normy prawnej, a także na problemie legitymacji prawnokarnej, definicji abstrakcyjnego narażenia i przedmiotu ochrony w odniesieniu do reguł wykładni prawa karnego.

Słowa kluczowe: niebezpieczeństwo, dobro prawne, teoria prawa karnego, przestępstwa abstrakcyjnego narażenia na niebezpieczeństwo, wykładnia prawa karnego, norma prawna.
\end{abstract}

\section{WSTECP}

Problematyka granic prawa karnego stanowi w dobie współczesnego społeczeństwa ryzyka jedno z ważniejszych zagadnień teoretycznych prawa karnego. Przede wszystkim problem granic stosowania, wykładni czy tworzenia prawa karnego dotyczy tzw. przestępstw abstrakcyjnego narażenia, które z perspektywy relacji ustawowego stanu faktycznego ${ }^{1}$ do przedmiotu ochrony ${ }^{2}$ można scharakteryzować za pośrednictwem kategorii braku zagrożenia in concreto (Giezek 2002,

\footnotetext{
*Uniwersytet Łódzki, Wydział Prawa i Administracji, Katedra Prawa Karnego, mateuszfil@ interia.pl

${ }^{1}$ Wykorzystuję terminologię Ryszarda Dębskiego, który definiuje ustawowy stan faktyczny jako: znamiona stanowiące element opisu czynu, zamieszczone w przepisie części szczególnej ustawy karnej (Dębski 1995, 100).

${ }^{2}$ Przez przedmiot ochrony rozumiem efekt wykładni teleologiczno-funkcjonalnej. W doktrynie prawa karnego przez przedmiot ochrony rozumie się wartość lub interes, inaczej dobro prawne, którego ochrona jest celem zakazu karnego stanowiącego treść normy sankcjonowanej. Niemniej status przedmiotu ochrony jako samodzielnego znamienia przestępstwa nie jest jednolicie postrzegany w doktrynie prawa karnego. Należy także odnotować, że paradygmat ochrony dobra prawnego jako aksjologiczno-teleologiczne założenie systemu prawa karnego stanowi wyłącznie zasadę, od której jednak występują wyjątki w ramach tzw. symbolicznego czy moralnego prawa karnego. Zob. Zoll 2011, 232; Kulesza 2014, 100, 102.
} 
118; Hryniewicz 2012, 20-22, 24, 35-36; Gruszecka 2012, 253-254 i 257-258; por. Hryniewicz 2013, 125; Filipczak 2014, 100) dla dobra prawnego. Ze względu na to, że zastosowanie prawa karnego, tj. pociągnięcie do odpowiedzialności karnej we wszystkich przypadkach formalnego wypełnienia znamion czynu zabronionego należącego do grupy przestępstw abstrakcyjnego narażenia budzi uzasadnione wątpliwości natury legitymacji prawa karnego (Hoyer 1987, 33; Graul 1991, 140-144; Wohlers 2000, 282 i n.; Giezek 2002, 121 i n.; Hryniewicz 2012, 45-56 i 119). W teorii prawa karnego pojawiły się odpowiednie próby ograniczenia czy też wyłączenia odpowiedzialności karnej, które można uznać za określone warunki przypisania odpowiedzialności za przestępstwa abstrakcyjnego narażenia na niebezpieczeństwo. $\mathrm{Z}$ tego względu przedmiotem opracowania jest przedstawienie zarysu teoretycznej odpowiedzi na pytanie o to, czy jest możliwa odpowiedzialność karna w przypadku braku zagrożenia dla dobra prawnego w ramach przestępstw abstrakcyjnego narażenia na niebezpieczeństwo. W związku z tak postawionym celem nasuwają się następujące pytania: jak rozumieć abstrakcyjne narażenie i czy brak zagrożenia dla dobra prawnego w ogóle może się pojawić w sytuacji, gdy określony czyn formalnie wypełnia znamiona czynu zabronionego należącego do typów rodzajowych określanych mianem abstrakcyjnego narażenia.

\section{RATIO LEGIS KONSTRUKCJI PRZESTĘPSTW ABSTRAKCYJNEGO NARAŻENIA NA NIEBEZPIECZEŃSTWO DOBRA PRAWNEGO}

W teorii prawa karnego wyróżnia się dwie standardowe koncepcje uzasadniające ratio legis konstrukcji przestępstw abstrakcyjnego narażenia ${ }^{3}$ : teorię generalnego niebezpieczeństwa ${ }^{4}$ (Graul 1991, 144; Wohlers 2000, 281-282; Giezek 2002, 118; Gruszecka 2012, 260-261) i teorię domniemywanego niebezpieczeństwa ${ }^{5}$ (Graul 1991, 151-152; Gruszecka 2012, 253-257). Obie z nich odnoszą się do powiązań

${ }^{3}$ Ponadto wskazuje się również na inne przyczyny uzasadniające, jak: pełniejszą ochronę dóbr prawnych, wypełnienie luk wytworzonych brakiem nieumyślnego usiłowania, usuwanie trudności dowodowych, eliminację przypadkowości wystąpienia skutku jako przesłanki odpowiedzialności karnej (Giezek 2002, 116).

${ }^{4}$ Teoria generalnego niebezpieczeństwa zakłada, że kryminalizowane zachowania są z natury niebezpieczne, a przynależność do tak określonej klasy uzasadnia decyzję o kryminalizacji. W ten sposób uzasadnienie zwraca się ku określeniu klasy zachowań z natury niebezpiecznych, a nie niebezpieczności samego zachowania in concreto. Określenie niebezpieczności takiej klasy zachowań odnosi się do kryterium prawdopodobieństwa, rozumianego jako powiązania kauzalne. Problematyczne przy tym jest określenie minimalnego stopnia tego prawdopodobieństwa.

${ }^{5}$ Teoria domniemanego niebezpieczeństwa zakłada przyjęcie domniemania, że dane zachowanie jest niebezpieczne. Wykorzystanie pojęcia domniemania warunkuje z kolei konieczność odpowiedzi na pytanie o to, czy jest ono wzruszalne. 
kazualnych wykorzystywanych w procesie kryminalizacji ${ }^{6}$ i konstrukcji struktury przestępstwa - istoty czynu (Dębski 2013, 387) lub typu czynu zabronionego $^{8}$ (tamże, 386), stąd słuszne jest ujęcie abstrakcyjności narażenia w kategoriach prognozy następstw podjęcia określonych zachowań (por. Giezek 2002, 133). Abstrakcyjność narażenia wyjaśniana w kategoriach braku zagrożenia in concreto dla dobra prawnego sprowadza się do tego, że abstrakcyjny opis czynu zabronionego zawarty w przepisach części szczególnej i ogólnej kodeksu karnego ${ }^{9}$ przedstawia jedynie prognozę wyrażającą prawdopodobieństwo „epistemologiczne"10 zaistnienia negatywnych następstw, do których przyczynia się lub też stanowi wręcz pierwotną przyczynę zachowanie wyznaczone opisem czynu zabronionego (por. Spotowski 1990, 164-167). Ocena wyrażona pojęciem prawdopodobieństwa dotyczy powiązań kauzalnych, a na płaszczyźnie normatywnej odrębnej od tego pojęcia sprowadza się do uznania, choćby a priori, negatywności samego następstwa, rozważenia, czy zachowanie-przyczyna może być pozytywnie wartościowane czy też z założenia można mu przypisać wyłącznie negatywną funkcję w społeczeństwie ${ }^{11}$. Wyjaśniając to na przykładzie, jak podaje Jacek Giezek, znamię „w stanie nietrzeźwości” przekształca pierwotnie legalną i - należy też dodać - pozytywnie wartościowaną czynność prowadzenia pojazdu mechanicznego w zachowanie zabronione pod groźbą kary kryminalnej (Giezek 2002, 128). Ratio legis takiego przekształcenia wynika z prawdopodobieństwa epistemologicznego zaistnienia negatywnych następstw w postaci wypadków komunikacyjnych czy też innego rodzaju naruszeń mienia, zdrowia czy narażenia życia.

${ }^{6}$ Kryminalizacja to „ustanawianie bądź modyfikacja istniejących typów w celu rozszerzenia granic karalności albo utrzymywanie istniejących typów rodzajowych”. Dekryminalizacja to „,rezygnacja z karalności w ogóle bądź ograniczenie zakresu karalności” (zob. Kulesza 2014, 88-89).

${ }^{7}$ Znamiona charakteryzujące czyn jako naruszający zakaz lub nakaz tworzą w ten sposób normę postępowania, a więc są to znamiona wskazujące zachowania typowe bezprawne „domniemanie". Do znamion należą te określone w części ogólnej z wyjątkiem strony podmiotowej oraz pozaustawowe znamiona uzupełniające, jak naruszenie/narażenie dobra prawnego, naruszenie reguł postępowania $\mathrm{z}$ dobrem prawnym

${ }^{8}$ Obejmuje przedmiotowe i podmiotowe elementy opisu zachowania, znamiona strony podmiotowej oraz znamiona uzupełniające charakteryzujące stanowisko gwaranta, znamiona naruszenia i narażenia dobra prawnego stanowiącego przedmiot zamachu, znamiona naruszenia reguł postępowania $\mathrm{z}$ dobrem prawnym (przedmiot ochrony). Tym samym jest on rekonstruowany zarówno w oparciu o expressis verbis wyrażone znamiona w przepisie karnym, jak i uzupełniające tzw. znamiona pozaustawowe.

${ }^{9}$ Dotyczy to również tzw. pozakodeksowego prawa karnego, z zastrzeżeniem, że tzw. administracyjne prawo karne nie jest oparte na paradygmacie ochrony dobra prawnego, choć wymaga to odrębnego opracowania monograficznego.

${ }^{10}$ Przez pojęcie prawdopodobieństwa epistemologicznego rozumie się wnioskowanie oparte na wiedzy (Hand 2015, 82-86). Na temat pojęcia prawdopodobieństwa w prawie karnym zob. Spotowski 1990, 39-42.

${ }^{11} \mathrm{Na}$ temat relacji pojęcia niebezpieczeństwa do pojęcia ryzyka w prawie karnym zob. Spotowski 1990, 300-303. 
Przy tak zakreślonych ramach abstrakcyjnego narażenia, z kategorii przestępstw abstrakcyjnego narażenia można niejako wyrzucić wszystkie typy czynu zabronionego, które sprowadzają się wyłącznie do negatywnej oceny zachowania, tj. już samo zachowanie zawarte w opisie czynu jest negatywne, co dotyczy tzw. administracyjnego prawa karnego, np. „Kto, będąc obowiązany do podania uprawnionym organom informacji dotyczących banku i klientów banku w zakresie ustalonym $\mathrm{w}$ ustawie, podaje nieprawdziwe lub zataja prawdziwe dane" (art. 171 ust. 4 Prawa bankowego), czy moralnego prawa karnego, np. kazirodztwo (art. 201 k.k.). Takie ujęcie jest wysoce pożądane, ponieważ, jak słusznie zwraca uwagę doktryna prawa karnego, dotychczasowo przestępstwa abstrakcyjnego narażenia stanowią jedną amorficzną masę, do której wrzuca się wszystkie czyny, które nie pasują do przestępstw z konkretnego narażenia czy przestępstw materialnych (Gruszecka 2012, 274, przyp. 625). W ten sposób nie dostrzega się oczywistych różnic $\mathrm{w}$ obrębie poszczególnych przestępstw, jak np. art. $182 \S 1$ k.k., art. 178a $\S 1$ k.k., art. $263 \S 2$ k.k., czy art. 201 k.k. Prowadzi to zreszta do wniosku, że wszystkie przestępstwa abstrakcyjnego narażenia stanowią przestępstwa formalne ${ }^{12}$, co jednak może budzić wątpliwości z perspektywy przypisania przestępstw abstrakcyjnego narażenia ${ }^{13}$. Ostatecznie również kategoria przestępstw z naruszenia przestaje być jednoznaczna, ponieważ część z szeroko pojmowanych przestępstw abstrakcyjnego narażenia, jak np. kazirodztwo, może być również przyporządkowana do naruszenia dobra prawnego, a wówczas narusza to ontologiczną strukturę pojęcia naruszenia jako pojęcia prawniczego ${ }^{14}$, ponieważ odnosi się zarówno do naruszenia jako skutku, np. rozstrój zdrowia, jak i naruszenia jako zachowania, np. kazirodztwo. Z tego względu z perspektywy przypisania odpowiedzialności karnej za przestępstwa abstrakcyjnego narażenia ograniczenie tej kategorii przestępstw jest potrzebne i praktycznie doniosłe, gdyż implikuje określone warunki, których zaistnienie umożliwia sądowi zastosowanie

${ }^{12}$ Takie stanowisko przyjmują Jacek Giezek i Piotr Kardas (Giezek, Kardas 2002, 10-14).

${ }^{13}$ Pomijając to, że większość doktryny prawa karnego przyjmuje stanowisko o krzyżowaniu się przestępstw materialnych i formalnych z przestępstwami odpowiednio naruszenia i konkretnego narażenia (przestępstwa skutkowe) i abstrakcyjnego narażenia (przestępstwo formalne) (Filipczak 2013, 136-137 i literatura tam podana). Najdalej idące stanowisko wyraża Elżbieta Hryniewicz, która stwierdza, że każde z przestępstw abstrakcyjnego narażenia może być ujęte jako przestępstwo materialne (Hryniewicz 2013).

${ }^{14}$ Rozumiem przez to warunek, że każde pojęcie prawnicze w swej ontologicznej strukturze odnosi się do poszczególnych konstrukcji prawniczych, np. typów przestępstw, i z tego względu musi zachować warunek jednolitości rozumienia jej części składowych, w przeciwnym razie w jej skład wchodzić mogą różne od siebie konstrukcje prawnicze, co z kolei czyni niezdatnym dla procesu systematyzacji prawa dane pojęcie prawnicze. Przykładowo, przy różnej definicji skutku jako znamienia czynu zabronionego pojęcie przestępstwa materialnego staje się niezdatne do systematyzacji typów przestępstw, do których należy skutek. Z perspektywy przestępstw abstrakcyjnego narażenia tak rozumiany warunek jednolitości został wykorzystany przez Andreasa Hoyera w analizie przestępstw zdatności (Hoyer 1987, 18, 22 i n.). 
normy prawnokarnej ${ }^{15}$. Jest rzeczą oczywistą, że inaczej wygląda proces przypisania odpowiedzialności karnej za czyn zabroniony z art. $182 \S 1$ k.k. i z art. 178a $\S 1$ k.k., z uwagi na to, że do pierwszej z nich zastosowanie ma tzw. klauzula zdatności, a drugi opis ustawowego stanu faktycznego jest przynajmniej prima facie jej pozbawiony. W związku z tym wskazana różnica powinna znaleźć swoje odzwierciedlenie teoretyczne w strukturze przestępstwa i warunkach przypisania odpowiedzialności karnej.

\section{LEGITYMACJA PRZESTĘPSTW ABSTRAKCYJNEGO NARAŻENIA}

Problem legitymacji przestępstw abstrakcyjnego narażenia można sprowadzić do pytania o granice odpowiedzialności karnej za zachowania, które jedynie mogą, choć wcale nie muszą doprowadzić do negatywnych następstw. Naturalnie pierwotnie problem ten dotyczy tworzenia prawa karnego, ponieważ to na tym etapie praktycznie możliwe jest przeprowadzenie hipotetycznej oceny związku przyczynowego (Gruszecka 2012, 254). Niemniej świadome stosowanie prawa karnego wymaga, aby w procesie decyzyjnym organu stosujaccego prawo zostało uwzględnione, a przynajmniej nie zostało naruszone ratio legis systemu prawa karnego. $Z$ tego względu w ramach przestępstw abstrakcyjnego narażenia słuszne jest podanie w wattpliwość czysto formalistycznego podejścia do przypisania odpowiedzialności karnej sprowadzającej się wyłącznie do oceny tego, czy doszło do realizacji ustawowego zespołu znamion przestępstwa. Do podstawowych instrumentów wykładni i stosowania prawa karnego umożliwiającego zachowanie warunku ratio legis zalicza się przedmiot ochrony i reguły postępowania $\mathrm{z}$ dobrem prawnym, które stanowić mają samodzielne znamiona uzupełniające.

Z uwagi na to, że abstrakcyjne narażenie w sensie ontologicznym in concreto ${ }^{16}$ nie przedstawia zagrożenia dla dobra prawnego, ale jedynie możliwość narażenia lub naruszenia dobra prawnego, pojawia się problem, czy pociagnięcie do odpowiedzialności karnej za zachowanie, które in concreto nie może doprowadzić do takiego narażenia lub naruszenia, nie narusza standardów ratio legis systemu prawa karnego.

Odwołując się do doktryny niemieckiej, problem legitymacji przestępstw abstrakcyjnego narażenia może zostać rozwiązany poprzez ograniczenie lub wyłączenie odpowiedzialności karnej, co można osiagnąć przez następujące konstrukcje prawnicze (Baroke 2011, 265-271; Otto 2005, 432):

${ }^{15} \mathrm{Na}$ potrzeby tego opracowania przyjęta jest ontologiczna koncepcja normy jako decyzji sędziowskiej. Na temat takiej konstrukcji teoretyczno-prawnej-Woleński 1980, 89-90, a na temat wykładni operacyjnej wykorzystującej taką konstrukcję normy prawnej - Płeszka 2010, 129-136.

${ }^{16}$ Nawiązuje do pojęcia potencjalności zagrożenia w sensie ontologicznym in concreto czynu (Filipczak 2014, 100). 
- Gegenbeweis der Ungefährlichkeit des Verhaltens im Einzelfall (przeciwdowód braku niebezpieczności zachowania in concreto) (zob. Brehm 1973, 126-138; Schröder 1967; Schröder 1969);

- Tatbestand-Ergänzung ist durch das geschriebene oder ungeschriebene ${ }^{17}$ Tatbestand-Merkmal der generellen Eignung der Handlung/Tat zur Rechtsgutsbeeinträchtigung zu ergänzen (wypełnienie znamion czynu uzupełnione o ustawowe lub pozaustawowe znamię generalnej zdatności zachowania do naruszenia/ narażenia dobra prawnego) (zob. Hoyer 1987);

- Strafbarkeit nur bei sorgfaltswidriger Gefährdung (karalność narażenia tylko w wyniku naruszenia reguł ostrożności);

- Strafausschließungsgrund bei absoluter Unmöglichkeit des Schadenseintritts im Einzelfall (okoliczność wyłączająca karalność przy absolutnej niemożliwości wywołania szkody w konkretnym przypadku);

- Ablehnung derartiger Restriktionen angesichts der gesetzgeberischen Entscheidung (rezygnacja $\mathrm{z}$ tego rodzaju przestępstw na podstawie decyzji ustawodawcy) (zob. Zieshang 1998, 380; Gruszecka 2012, 280, przyp. 643).

Również w polskiej dogmatyce prawa karnego (Hryniewicz 2012, 280-283; Giezek 2002, 129 i n.) postuluje się ograniczenie odpowiedzialności karnej do przypadków, gdy zachowanie stanowi naruszenie reguł ostrożności, z czym związane jest nietolerowane ryzyko.

Należy zaznaczyć, że z perspektywy teoretycznej problem legitymacji przestępstw abstrakcyjnego narażenia może być rozwiązany jedynie przez ograniczenie lub wyłączenie odpowiedzialności karnej, ponieważ w przypadku gdy za uzasadnioną, tj. nienaruszającą ratio legis systemu prawa karnego, uznaje się odpowiedzialność karną, pomimo wyjątkowego braku zagrożenia dla dobra prawnego przy przestępstwie abstrakcyjnego narażenia, to $\mathrm{w}$ istocie $\mathrm{w}$ ogóle nie uznaje się omawianego przypadku za problem legitymacji prawa karnego. $\mathrm{Z}$ takim podejściem teoretycznym spotkać się można w poglądach Andrzeja Spotowskiego, który uznaje karalność wyjątkowego braku zagrożenia dla dobra prawnego za wyraz zła koniecznego. W konsekwencji tego, problem legitymacji może być analizowany co najwyżej z perspektywy decyzji ustawodawcy.

W dalszym toku wywodu ograniczenie lub wyłączenie odpowiedzialności karnej jest analizowane wyłącznie z perspektywy „przeciwdowodu braku zagrożenia”, „,naruszenia reguł ostrożności” i „znamienia zdatności”, choć należy zaznaczyć, że celem jest przedstawienie ogólnego tła teoretyczno-dogmatycznego, ponieważ analiza każdej z osobna wymienionych konstrukcji prawniczych wymaga odrębnego samodzielnego wywodu monograficznego. $Z$ tego względu postanowiono arbitralnie na potrzeby tego opracowania analizować ,przeciwdowód braku zagrożenia" jako kategorię braku zagrożenia dla dobra prawnego i jako kategorię tolerowanego ryzyka, tj. braku zagrożenia prawnokarnie relewantnego. Przedstawione

${ }^{17}$ Zob. Hoyer 1987, 18 i n. 
pojęcia mają oczywiście rodowód teoretyczny, ale jeżeli pominie się terminologię teoretyczną, wydaje się, że rozumowanie przeprowadzane z ich wykorzystaniem stanowić powinno istotną wskazówkę dla świadomego stosowania prawa karnego i chyba, co bardziej interesujące dla praktyki, mającą istotną wartość dla procesu przypisania odpowiedzialności karnej i uzasadnienia decyzji sądu.

\section{FIGURA PRAWNICZA „PRZECIWDOWODU BRAKU ZAGROŻENIA”}

Przedstawiając obrazowo problem przeciwdowodu braku zagrożenia, można wykorzystać problematykę naruszenia i zagrożenia dobra idealnego, wykorzystując przy tym źródłowe przestępstwo abstrakcyjnego narażenia na niebezpieczeństwo (art. 178a $\S 1$ k.k.).

Można powiedzieć, że sprawca jadąc w stanie nieznacznego wpływu alkoholu, nie stwarza większego niebezpieczeństwa niż kierowca przekraczający prędkość. Jednak tylko pierwsze zachowanie pociaga odpowiedzialność karną, a drugie pozostaje w sferze wykroczeń. Nie znajduje to żadnego sensownego uzasadnienia, jeżeli zwrócimy uwagę na to, że stan nietrzeźwości o stopniu niewielkiego oddziaływania na zdolności motoryczne kierowcy jest w znacznej mierze ontologicznie mniej niebezpieczny niż rażące niedostosowanie prędkości. W obu przypadkach powiemy, że niebezpieczeństwo uzasadniające kryminalizację tkwi w potencjalnym charakterze takich kierowców jako sprawców wypadku komunikacyjnego. Jednakże takie rozumowanie jest błędne, ponieważ nie sposób w żaden sposób postawić znaku równości pod względem ontologicznym wobec tych dwóch sytuacji. W tych jednak przypadkach kierowca - ,,pirat drogowy”popełnia wykroczenie, a kierowca w stanie nietrzeźwym przestępstwo. Obrazuje to błędne założenie o potencjalnym charakterze jako „zabójców drogowych” kierowców w stanie nietrzeźwym. Teoria domniemanego niebezpieczeństwa legitymująca przestępstwa abstrakcyjnego narażenia zakłada, że wprowadzenie domniemania niebezpieczeństwa zachowania uzasadniają trudności dowodowe. Niemniej należy mieć na uwadze, że w ogóle nie mówi ona o tym, czy takie domniemanie jest wzruszalne. Jeżeli przyjrzeć się kryterium trudności dowodowych w powiązaniu z celem, jakim jest ochrona dóbr, może zostać uznany za prawidłowy ten kierunek rozważań.

Nadal pozostaje otwarta kwestia, jak ustalić prawidłowo domniemanie. Dlaczego arbitralna decyzja wyznaczająca granice odpowiedzialności karnej na 0,5 promila, a nie 0,2, 1,0, czy 0,0 promila, jest prawidłowa. Czy chodzi o statystycznie ujęte obniżenie czasu reakcji czy może ogólnie przyjętej reakcji na alkohol? Przykładowo, jeżeli weźmiemy próg 0,5-0,6 promila alkoholu we krwi, to można stwierdzić, że powoduje on błędną ocenę własnych możliwości, znaczne obniżenie samokontroli i koncentracji, nadmierną pobudliwość (Potocka-Banaś, Borowiak, Janus 2008, 228; Buttler 2014, 7-8; Raszeja, Nasiłowski, Markiewicz 
1990, 221-222). Wszystkie te cechy można zaobserwować również u osób, które nie spożyły alkoholu, a jako przykład można podać zarówno określone zaburzenie fizjologiczne, jak i psychologiczne: informacja o narodzinach dziecka itd. (Raszeja, Nasiłowski, Markiewicz 1990, 163-164). Dopiero od 0,7-0,8 promila wskazuje się na zdecydowane osłabienie koordynacji mięśniowej i zdolności prowadzenia pojazdu, a jednoznaczne obniżenie zdolności psychomotorycznych następuje dopiero w fazie euforycznej (stężenie powyżej 1 promila alkoholu we krwi) (Raszeja, Nasiłowski, Markiewicz 1990, 222). Należy również zaznaczyć, że stopień i natężenie wpływu alkoholu na organizm są uzależnione od dawki, wieku, stanu odżywienia, a nawet od samego rodzaju i sposobu spożycia alkoholu (Raszeja, Nasiłowski, Markiewicz 1990, 223). Czy jednak posłużenie się znamieniem zdatności dla takich przypadków w znaczący sposób nie utrudni ochrony dóbr przez problemy natury dowodowej. Oczywiście, że tak, ale nie chodzi o to w tym miejscu wywodu. Chodzi zatem o to, że ustawodawca nie może za pośrednictwem określonych kryteriów dokonać kryminalizacji określonego zachowania, a innego, które niczym się według tych kryteriów od niego nie różni, pozostawić bezkarnym. W związku z tym ustawodawca powinien albo kryminalizować oba jednocześnie, albo pozostawić je bezkarne. Innej możliwości zgodnej z logicznym rozumowaniem po prostu nie ma.

Możliwe jest również uzasadnienie kryminalizacji jazdy w stanie nietrzeźwym na nieco innej płaszczyźnie niż niebezpieczeństwo rozumiane jako sytuacja potencjalnie prowadząca do naruszeń. Chodzi mianowicie o wyeliminowanie zachowań ryzykownych (zob. Brehm 1973, 139; Gruszecka 2012, 261 i 270). Ustawodawca chce w ten sposób w ogóle zabronić zachowania podejmowanego umyślnie. Niebezpieczeństwo czynu i jego skutki pozostają jako komponenty oceny na płaszczyźnie prawnokarnie relewantnego niebezpieczeństwa, ale zmienia się uzasadnienie zastosowania metody prawnokarnej. Innymi słowy, nadal pozostawiamy kryterium potencjalnych naruszeń „kierowcy-zabójcy”, ale ocena karalności polega na uzasadnieniu zastosowanej metody, która jest - i może być - inna w stosunku do pirata drogowego i inna w stosunku do nietrzeźwego kierowcy. W tym duchu można zadać sobie pytanie, czy nie byłoby lepiej w ujęciu prewencyjnym przestępstw abstrakcyjnego narażenia - a takie w większości jest reprezentowane - posłużyć się zastosowaniem samego środka karno-administracyjnego, jakim jest zakaz prowadzenia pojazdów. Jeżeli sprawca zostałby zatrzymany, to równie dobrze postępowanie mogłoby mieć na celu nie zasądzenie właściwej kary, ale wyeliminowanie przynajmniej teoretyczne przyczyny. Taki kierowca mógłby być prewencyjnie karany zakazem prowadzenia pojazdów na okres co najmniej trzech miesięcy, po czym zwracano by mu prawo jazdy. Jeżeli ponownie zostałby złapany w przeciagu powiedzmy dwóch lat, prawo jazdy zostałoby mu zabrane ponownie, ale już na okres przykładowo roku i dodatkowo kierowca zostałby skierowany na badania medyczne. Jeżeli ponownie zostałby złapany, prawo jazdy zostałoby mu zabrane dożywotnio, przy czym mógłby się 
ponowne ubiegać o nie po odpowiednim okresie karencji i pozytywnej weryfikacji w zakresie alkoholizmu. Czemu miałoby to jednak służyć? Otóż wyznaczone okresy pozwalają na ocenę zachowania kierowcy jako alkoholika albo niealkoholika, który po „prostu” lekceważy prawo. Alkoholik pozbawiony możliwości prowadzenia pojazdu przestaje być niebezpieczny, jeżeli istota zagrożenia leży wyłącznie w prowadzeniu pojazdów w stanie nietrzeźwym.

Dotychczasowe rozważania skupiły się na wartościach brzegowych nietrzeźwości i dlatego też należałoby się przyjrzeć również problematyce prowadzenia pojazdu w stanie istotnie nietrzeźwym. Od razu można wskazać na niedookreśloność pojęcia istotna, czy też duża, znacząca etc. nietrzeźwość. Zabieg ten był celowy i miał za zadanie zobrazować trudności w kryminalizacji zachowania. Z cała pewnością arbitralnie w sposób absolutny z przyczyn już podniesionych nie sposób tego ocenić. Tym samym zasadne jest posłużenie się konstrukcją przestępstwa zdatności. W ten sposób w przypadkach skrajnych i statystycznie wyjątkowych tacy kierowcy spotkaliby się z surowszą reakcją w postaci odpowiedzialności karnej za przestępstwo zdatności do spowodowania wypadku. W pozostałych wypadkach czyn pozostawałby w sferze administracyjno-wykroczeniowej. Oczywiście sprawne funkcjonowanie takiego systemu uzależnione byłoby od sprawności aparatu policyjnego i sądowo-prokuratorskiego. Mając jednak o to obawy, można byłoby wprowadzić granice, powiedzmy do 0,5 promila traktowanie jako zawsze wykroczenia, ale już powyżej tej granicy kwestia tego, czy czyn pozostaje wykroczeniem, czy też jest przestępstwem, musiałaby być zbadana w postępowaniu karnym. Przy tym jednocześnie zmian wymagałoby prawo wykroczeń, aby nie dopuścić do przedawnienia karalności wykroczenia w czasie prowadzonego postępowania karnego. Tych problemów nie byłoby jednak, gdyby zamiast kwalifikowania czynu jako wykroczenia posłużyć się sankcją administracyjną, zabraniająca jazdy w stanie po użyciu alkoholu i uzależniającą czas, na jaki odbierano by prawo jazdy, od ilości alkoholu znajdującego się w organizmie kierowcy. Pozostawiając jedynie, jako przestępstwo zdatności, jazdę w stanie nietrzeźwym, dla którego to typu przestępstwa można byłoby także dla uproszczenia stosowania prawa ustanowić minimalną granicę w wysokości 0,5 promila. Poniżej tej granicy niweczyłoby to całe założenie, a powyżej mogłoby pozostawić poza granicami kryminalizowanego zachowania czyny, które byłyby zdatne do naruszeń. Przykładowo, przejeżdżanie w stanie wskazującym 0,6 promila alkoholu obok szkoły, zgodnie z ogólną kauzalnością, jest czynem zdatnym do naruszeń, bo dzieci mogą wybiec na drogę, a czas reakcji kierowcy jest znacząco opóźniony. Można przyjąć, że prawdopodobieństwo epistemologiczne (tj. oparte na wiedzy) zajścia negatywnego zdarzenia (naruszenia/narażenia życia lub zdrowia człowieka/dziecka) jest wyższe w sytuacji przejeżdżania samochodem przez kierowcę posiadającego 0,6 promila alkoholu we krwi obok szkoły podstawowej w czasie, w którym zaczynają się lub kończą lekcje niż przy tym samym stężeniu alkoholu ( 0,6 promila), ale w późnych porach nocnych na uliczkach osiedlowych. Naturalnie rozważana 
jest wyłącznie zdatność do naruszenia/narażenia dóbr prawnych (życia i zdrowia) z perspektywy prawidłowego prowadzenia pojazdu mechanicznego (tj. zgodnie z zasadą bezpiecznej prędkości itd.) i faktycznego wpływu alkoholu na zdolności psychomotoryczne kierowcy (por. Hoyer 1987, 107-108).

Ostatecznie warto choćby z uwagi na wskazane przyczyny krymino-polityczne i problemy tworzenia prawa karnego zastanowić się na dopuszczeniem przeciwdowodu braku zagrożenia, który regulowałby graniczne przypadki stosowania prawa karnego w obszarze przestępstw abstrakcyjnego narażenia przez zmiany treści ustawy.

Kolejnym przykładem ilustrującym przeciwdowód braku zagrożenia jest sytuacja, w której osoba mająca pozwolenie na posiadanie broni palnej znalazła w domu swoich zmarłych rodziców starą i pozbawioną cech użytkowych broń. $\mathrm{Z}$ uwagi na to, że brak wiedzy na temat jej pochodzenia uniemożliwia zarejestrowanie takiej broni, postanawia pozostawić ją zabezpieczoną w miejscu, w którym przechowuje swoją zarejestrowaną broń palną. Z uwagi na to, że broń jest pozbawiona cech użytkowych, prawdopodobieństwo następstwa zaistnienia negatywnego stanu rzeczy jest równe zeru, a więc stanowi zdarzenie niemożliwe. Wykorzystując definicję ogólną pojęcia zdatności ${ }^{18}$, można powiedzieć, że z uwagi na właściwość braku cech użytkowych broni nie może ona być wykorzystana jako broń palna - narzędzie, którym posłużenie się narusza życie lub zdrowie człowieka. Prowadzi to do wniosku, że wskazany hipotetyczny stan rzeczy nie jest zdatny doprowadzić do naruszenia życia lub zdrowia. $Z$ tego względu dana osoba nie powinna ponieść odpowiedzialności karnej za przestępstwo z art. $263 \S 2$ k.k., pomimo że z formalnego punktu widzenia posiada broń palną pozbawioną cech użytkowych bez wymaganego zezwolenia (posiadanie broni palnej pozbawionej cech użytkowych jest zgodnie z ustawą dopuszczalne na podstawie certyfikatu rejestracji). Niemniej posiadacz może ponieść odpowiedzialność za wykroczenie $\mathrm{z}$ art. 51 ust. 2 pkt 1 ustawy o broni i amunicji ${ }^{19}$.

W związku z przedstawionymi uwagami można powiedzieć, że dopuszczalność przeciwdowodu braku zagrożenia opiera się na uprzednim założeniu, że istotą bezprawia czynu z art. $263 \S 2$ k.k. nie jest każdorazowe naruszenie przepisów prawnych, a tylko takie naruszenie, które wiąże się z zagrożeniem dla dobra prawnego życia i zdrowia. Taki rezultat można osiągnać, gdy uzna się, że naruszenie przepisów $\mathrm{w}$ sensie formalnym powinno być sprzężone z przepisami konstytuującymi reguły ostrożności, które w sposób bezpośredni odnoszą się do ochrony życia i zdrowia (prawidłowe przechowywanie broni) (a) lub naruszenie jakiegokolwiek przepisu w sensie formalnym jest jednocześnie naruszeniem reguł

18 „Pod pojęciem zdatności należałoby rozumieć stosownie do tego właściwość stanu rzeczy (stanu rzeczy wyjścia), mogącą wywołać inny stan rzeczy (stan rzeczy odniesienia)" (Hoyer 1987, 30).

${ }^{19}$ Tej samej karze (aresztu albo grzywny w zw. z ust. 1) podlega ten, kto nie dopełnia obowiązku rejestracji broni albo obowiązku zdania broni i amunicji do depozytu. 
postępowania z dobrem prawnym życia i zdrowia (b). W pierwszym przypadku (a) treść art. $263 \S 2$ k.k. musiałaby zawierać zwrot typu „kto narusza przepisy ustawy, posiadając lub wchodząc w posiadanie broni palnej, podlega karze". Wówczas możliwe jest uwzględnienie kontekstu ochronnego w ten sposób, że naruszenie przepisów w sensie formalnym zostanie ograniczone wyłącznie do tych, które służą bezpośrednio ochronie życia i zdrowia. W drugim przypadku (b) pomimo tego, że w hipotetycznym stanie faktycznym formalnie doszło do wypełnienia znamion, to jednak taki stan faktyczny świadczy o braku naruszenia reguł postępowania $z$ dobrem prawnym: życia i zdrowia, a jedynie o naruszeniu przepisów prawa administracyjnego.

Podsumowując, można powiedzieć, że w przypadkach (a) i (b) chodzi o interpretację ,porządku publicznego" jako wyrażającego zbiór wszelkich przepisów prawnych w sensie materialnym chroniącym dobra o charakterze indywidualno-konkretnym, który to porządek zapewnia ochronę przez ustanowienie określonych przepisów administracyjnych. Wskazana interpretacja stanowi przykład wykładni prokonstytucyjnej, która oparta jest na rozumieniu ,porządku publicznego" w ramach art. 31 ust. 3 Konstytucji RP z perspektywy zewnętrznych granic prawa karnego. Zgodnie z przywołanym postanowieniem polskiej ustawy zasadniczej, ograniczenie wolności ${ }^{20}$ poprzez ustanowienie odpowiedzialności karnej jest możliwe tylko wówczas, gdy kryminalizacja jest konieczna w demokratycznym państwie dla zapewnienia jego bezpieczeństwa i porządku publicznego. Tym samym tytuł rozdziału ,przestępstwa przeciwko porządkowi publicznemu” należy rozumieć w kontekście art. 31 ust. 3 jako jego realizacje. Należy zwrócić uwagę, że wskazane przepisy Konstytucji RP dotyczą wszystkich gałęzi prawa. Z tego względu porządek publiczny w prawie karnym należałoby rozumieć jako zbiór przepisów chroniących dobra konkretno-indywidualne lub szczególne wartości kolektywne. Tym samym przedmiotem zamachu nie jest porządek prawny jako taki, czyli naruszenie przepisów w sensie formalnym, ale porządek prawny zapewniający ochronę dobrom indywidualno-konkretnym, w myśl założeniom nauki o dobru prawnym niewłaściwy jest tok rozumowania, że ,,posiadana niezgodnie z wymogami ustawy broń, tzn. bez wymaganego zezwolenia, a tym samym bez możliwości sprawowania przez właściwy organ nadzoru nad prawidłowością jej używania i przechowywania, stanowi zagrożenie dla porządku publicznego" (Wyrok WSA w Warszawie z dn. 16 października 2007 r., VI SA/Wa 1502/07,

${ }^{20}$ Należy zwrócić uwagę, że nie chodzi o wolność jako powszechny dostęp do posiadania broni palnej, która nie jest prawem obywatelskim ani prawem człowieka, zob. wyrok NSA z dn. 16 września 2014 r., II OSK 583/13, LEX nr 1664489: Osoby ubiegające się o pozwolenie na broń powinny dawać rękojmię przestrzegania bezpieczeństwa i porządku publicznego. Tym bardziej iż prawo posiadania broni nie należy w Polsce do praw obywatelskich gwarantowanych w Konstytucji RP. Prawo do posiadania broni ma w świetle omawianej ustawy charakter reglamentacyjny, zatem osoby posiadające pozwolenie na broń powinny w sposób szczególny unikać kolizji z prawem i należy od nich wymagać nieskazitelnej postawy. 
LEX nr 399259). Czyn z art. 263 k.k. należy rozumieć zatem jako przestępstwo przeciwko porządkowi publicznemu (przepisom prawnym) chroniącemu życie i zdrowie. W ten sposób typ czynu zabronionego z art. $263 \S 2$ k.k. interpretować można jako przestępstwo abstrakcyjnego narażenia życia lub zdrowia, a nie przestępstwo z naruszenia porządku publicznego. W zależności od tego, czy ustawowe znamiona konkretnego typu czynu z art. 263 k.k. umożliwiają powiązanie naruszenia reguły postępowania $\mathrm{z}$ dobrem prawnym w sposób bezpośredni z realizacją znamion np. art. $263 \S 3$ i 4 [przypadek (a)], czy też odniesienie do reguł postępowania $\mathrm{z}$ dobrem prawnym uzyskujemy $\mathrm{w}$ drodze wykładni [przypadek (b)], czyn zabroniony z art. $263 \S 2$ k.k., jeżeli stanowić ma przestępstwo abstrakcyjnego narażenia, to odnosi się do życia i zdrowia, a jeżeli traktuje się go jako przestępstwo z naruszenia, to wówczas nie chroni on dobra prawnego, ale stanowi przykład tzw. administracyjnego prawa karnego.

\section{ROLA W PROCESIE WYKLADNI PRAWA KARNEGO}

Ujawniony wątek relacji nazwy tytułu rozdziału czy też szerzej nazwy ustawy w procesie interpretacji prawa karnego wymaga jednak kilku uwag ze względu na doniosłość praktyczną. W dogmatyce prawa karnego przyjęło się, że tytuł rozdziału przesądza o przedmiocie ochrony. Świadome stosowanie prawa karnego, a przynajmniej nieformalistyczne podejście do jego stosowania, wymaga jednak szerszego spojrzenia na problematykę przedmiotu ochrony, dobra prawnego i ratio legis (zob. Matczak 2007). W doktrynie prawa karnego wskazuje się, że rozdział, a ściślej nazwa rozdziału (Wróbel 2009, 623-629) lub tytuł ustawy przesądza o ratio legis, a więc przedmiocie ochrony typu rodzajowego czynu zabronionego. Należy zaznaczyć, że wskazane stanowisko stanowi konsekwencję założeń teoretycznych norm sprzężonych w prawie karnym. W myśl poglądów Włodzimierza Wróbla nie tylko norma sankcjonująca, ale również norma sankcjonowana wynika $\mathrm{z}$ przepisów prawnokarnych, a operatorem deontycznym „zakazu” dla konstrukcji normy sankcjonowanej zakazującej określonego zachowania jest treść art. $115 \S 1$ k.k. (Wróbel 1993, 101), który stanowi o definicji legalnej czynu zabronionego. Pomijając argumenty logiczne w rozumieniu systemu logicznego krytyczne w stosunku do takiej możliwości, należy wskazać, że sam fakt umiejscowienia danego przepisu w określonym rozdziale nie musi przesądzać o przedmiocie ochrony. Jeżeli dobru prawnemu nadamy wyższą rangę, tj. pierwotną w stosunku do woli ustawodawcy, to siłą tej teoretycznej rzeczy decyzja ustawodawcy nie może zmieniać istoty czynu godzącego w dobro prawne określonego rodzaju. Innymi słowy, to analiza poszczególnych znamion i ich ontologicznego otoczenia - tj. desygnatów, które denotują wyrażenia językowe wchodzące w skład zespołu znamion czynu zabronionego - decyduje o przedmiocie zamachu i również przedmiocie ochrony. $\mathrm{O}$ ataku na dobro prawne decyduje 
realizacja znamienia czasownikowego. Dobro prawne jest denotowane przez odzwierciedlenie ,przedmiotu odniesienia" dla realizacji znamienia czasownikowego, tj. zachowania. Przykładowo, dla średniego uszczerbku na zdrowiu zachowanie polegające na powodowaniu uszczerbku na zdrowiu odnosi się do konkretnego człowieka, a ów człowiek stanowi odzwierciedlenie dla dobra prawnego w postaci zdrowia. Kolejny argument przeciwko normatywnemu statusowi rozdziału lub szerzej treści tytułu aktu prawnego wynika ze struktury normy prawnej jako reguły postępowania. Schemat rozumowania przedstawia się następująco:

P1. Norma to reguła postępowania

P2. Norma składa się z wypowiedzi normatywnej (tekst ustawy)

W: Rozdział nie może być normą

Dowód D1: Jeżeli przyjęlibyśmy twierdzenie przeciwne do W, to musielibyśmy uznać, że:

A. reguła postępowania jest nakaz tworzenia przestępstw przeciwko przykładowo wolności skierowany do ustawodawcy; nakaz tworzenia przestępstw przeciwko przykładowo wolności.

B. każdy opis czynu znajdujący się w rozdziale zatytułowanym ,pprzestępstwa przeciwko wolności” jest przestępstwem przeciwko wolności.

Dowód D 1.2: Jeżeli przyjmujemy P1 i twierdzenie A skierowane do ustawodawcy, to powinniśmy uznać, że każdy z przepisów zawartych w rozdziale jest spełnieniem normy, a jeżeli tak jest, to w istocie każdy z nich jest konstytucyjnym wypełnieniem zadania ustawodawcy ${ }^{21}$.

Nie jest to już jednak do przyjęcia, ponieważ zawsze można go podważyć w ten sposób, że są jeszcze inne normy prawne, tj. pozostałe rozdziały. Ponadto można podnieść zarzut argumentacji błędnego koła, tj. legitymacja prawa wyprzedza jego typizację. W ramach analizowanego rozumowania byłoby odwrotnie, czyli norma prawna z treści rozdziału nakazuje tworzyć przestępstwa, a decyzja ustawodawcy jest legitymowana, ponieważ tak zapisywał to w rozdziale lub tytule aktu prawnego 22 .

Dowód D2. Na podstawie D1 i D1.2 oraz P1 i P2 można zauważyć, że co najwyżej powinniśmy uogólnić rozważania do wszystkich tytułów rozdziałów, a to z kolei prowadzi do wniosku, że przecież treść reguły odnajdujemy w wyrażeniach językowych ustawy zasadniczej, tj. rozdziały to nic innego jak odniesienie do aktu prawnego, czyli jego struktury tekstu, a decyzja ustawodawcy odnosi się do ustawy zasadniczej. Innymi słowy, z treści konstytucji można wywieść

${ }^{21} \mathrm{Na}$ temat problemu, czy treść konstytucji może przesądzać o nakazie kryminalizacji określonych zachowań zob. Wohlers 2000, 242-244.

${ }^{22}$ Podobny argument wysunięto w nauce o dobru prawnym, w ramach którego podniesiono, że nie można dowolnie podchodzić do dobra prawnego stanowiącego przedmiot ochrony, stwierdzając, że dane przestępstwo abstrakcyjnego narażenia chroni dobro kolektywne, w przeciwnym razie decyzja o kryminalizacji byłaby błędna (zob. Greco 2011, 207). Jak słusznie zwraca się uwagę, sam fakt wielości interesów lub wartości nie przesądza o kolektywności dobra prawnego (tamże, 210). 
wniosek, że reguła postępowania dla ustawodawcy jest przykładowo przeciwdziałanie narkomanii i dopiero wówczas ma on obowiązek ją wypełnić przez odpowiednie ustawodawstwo, czyli wprowadzenie wypowiedzi normatywnych, które są już skonkretyzowane, np. zakaz posiadania określonych substancji odurzających. Przyjęcie, że rozdział ma status samodzielnej dyrektywy interpretacyjnej, jest przemieszaniem uzasadnienia normy z treścią tej normy, a więc jest obarczone błędem przesunięcia kategorialnego.

Ostatecznie należałoby stwierdzić, że tytuł rozdziału lub tytuł ustawy mogą stanowić jedynie wskazówkę interpretacyjną, ale nie przesądzają jednoznacznie o przedmiocie ochrony i co więcej nie przesądzają o regułach postępowania $\mathrm{z}$ dobrem prawnym. Jako przykład można wskazać typ czynu zabronionego $\mathrm{z}$ art. $177 \S 1$ k.k. (wypadek komunikacyjny), w ramach którego reguły postępowania z dobrem prawnym są na poziomie zespołu znamion denotowane przez wyrażenie językowe „narusza zasady bezpieczeństwa w ruchu lądowym, wodnym lub powietrznym".

\section{PRZECIWDOWÓD BRAKU ZAGROŻENIA JAKO PRZESŁANKA ODPOWIEDZIALNOŚCI KARNEJ}

Powracając do problematyki przeciwdowodu braku zagrożenia jako elementu przypisania odpowiedzialności karnej za przestępstwa abstrakcyjnego narażenia, należy zaznaczyć, że opiera się on na założeniu, że niebezpieczeństwo dla dobra prawnego stanowi konstytutywny element przestępstwa, a tym samym przeciwdowód braku zagrożenia należy odnieść do pojęcia normy prawnokarnej, ponieważ przypisanie odpowiedzialności karnej utożsamić można z zastosowaniem normy prawnej. Należy wyraźnie zaznaczyć, że nie jest właściwym elementem struktury przestępstwa, w którym upatruje się miejsca dla ograniczenia czy wyłączenia odpowiedzialności karnej za przestępstwa abstrakcyjnego narażenia, społeczna szkodliwość czynu, która w przypadku braku zagrożenia lub tolerowanego ryzyka zachowania miałaby być znikoma, czy też w ogóle by nie miała miejsca. Jak zwraca uwagę Jacek Giezek, w ramach przeciwdowodu chodzi o ,ustalenie zakresu obowiązywania normy prawnokarnej, tzn. czy w ogóle nie wolno podejmować zachowań standardowo uznawanych za niebezpieczne, czy też zakaz dotyczy jedynie zachowań, które również in concreto faktycznie okazały się niebezpieczne" (Giezek 2002, 126, przyp. 24). Z kolei Elżbieta Hryniewicz wskazuje, że w toku wykładni ,,aby zachować legitymizację ingerencji ustawodawcy $[\ldots]$ konieczne jest nie tylko odtworzenie zakresu normy prawnej z językowej treści przepisu, lecz także uwzględnienie jej funkcji ochronnej, czyli ustalenie, że zaistniało co najmniej potencjalne zagrożenie przedmiotu ochrony". Z tego względu autorka włącza do ustawowego zespołu znamion karalności (por. Hryniewicz 2012, 281) takie zagrożenie, a tym samym jego brak decyduje 
o wyłączeniu z zakresu normy prawnokarnej zachowania, które nie zagraża dobrom prawnym (Hryniewicz 2012, 281-282). W konsekwencji przyjęcia takiego stanowiska, dodatkowo można powiedzieć, że figura braku zagrożenia dla dobra prawnego nie może stanowić także klauzuli niepodlegania karze, ponieważ odnosi się ona wyłącznie do czynu zabronionego, a w tym przypadku czyn ten w ogóle nie zaistnieje z uwagi na brak jednego ze znamion (por. Hryniewicz 2012, 146).

Należy zwrócić uwagę, że zarówno Elżbieta Hryniewicz, jak i Jacek Giezek nie przywiązywali wagi do różnicy teoretycznej pomiędzy brakiem niebezpieczeństwa a tolerowanym ryzykiem. Należy wyraźnie odróżnić pojęcie zachowania ryzykownego od pojęcia ryzyka, ponieważ pierwsze dotyczy przypisania odpowiedzialności karnej i tym samym mieści się już w ramach niebezpieczeństwa dla dobra prawnego prawnokarnie relewantnego (por. Gruszecka 2012), a drugie określa ramy prawnokarnej relewantności niebezpieczeństwa. Posługując się terminologią legitymowanych granic zewnętrznych (kontekst uzasadnienia zakresu kryminalizacji) i wewnętrznych (kontekst systemowy) prawa karnego (por. Filipczak 2016, 191-192), można powiedzieć, że zachowanie ryzykowne mieści się w granicach zewnętrznych, a wyznacza wewnętrzne granice prawa karnego, natomiast pojęcie ryzyka odnosi się zawsze do granic zewnętrznych. Brak niebezpieczeństwa zawsze warunkuje brak odpowiedzialności karnej w obrębie paradygmatu ochrony dobra prawnego (por. odmiennie Spotowski 1990, 167-168), ponieważ odpada istota funkcjonalno-teleologiczna normy prawnokarnej, której celem jest ochrona dobra prawnego, a zastosowanie tejże normy do sytuacji braku niebezpieczeństwa nie może służyć ochronie dobra prawnego. Inaczej rzecz przedstawia się w ramach zachowania ryzykownego, ponieważ w ramach tejże figury prawniczej wprowadzone zostają dodatkowe elementy, jak naruszenie reguł postępowania z dobrem prawnym, czy stopień koniecznej świadomości tych reguł, które warunkują odpowiedzialność karną za zachowania stanowiące abstrakcyjne narażenia dobra prawnego. Związane jest to $\mathrm{z}$ ramami tolerowanego ryzyka w obrębie zachowań stanowiących abstrakcyjne narażenia.

Niemniej kluczowe zagadnienie, jakie należy rozstrzygnąć, dotyczy relacji normy prawnokarnej do przedstawionych uwag Elżbiety Hryniewicz i Jacka Giezka. Z tej perspektywy wydaje się, że podstawowym punktem wyjścia jest przyjęcie, że przeciwdowodów braku zagrożenia dla dobra prawnego dotyczy obowiązywanie normy prawnokarnej. Należy odnotować, że wymienieni autorzy raczej posługują się dogmatycznym rozumieniem obowiązywania prawa (na temat granic takiego rozumowania zob. Wróblewski 2015, 250 i n.) niż konstrukcją teoretyczno-prawną (Grabowski 2009). Jacek Giezek stwierdza, że zakaz karny (norma prawnokarna) sprowadza się do co najmniej narażenia dobra prawnego na niebezpieczeństwo (Giezek 2002, 125). Natomiast Elżbieta Hryniewicz sprowadza obowiązywanie normy prawnokarnej do istnienia społecznego niebezpieczeństwa cechującego pewne zachowania w określonych okolicznościach z uwagi na wiążące się z nimi zagrożenie istotnych społecznych wartości (Hryniewicz 
2012, 280). Kluczem do odkodowania sposobu rozumowania przyjętego przez autorów jest, oprócz naczelnego założenia o ochronie dobra prawnego, a które na poziomie struktury przestępstwa oznacza niebezpieczeństwo dla dobra prawnego jako znamię istoty czynu zabronionego, także tzw. znamię zdatności. Wydaje się, że autorzy odwołując się do obowiązywania normy prawnokarnej i odpowiedniego rozumienia zakazu karnego, powinni uwzględnić znamię zdatności w obrębie każdego przestępstwa abstrakcyjnego narażenia na niebezpieczeństwo dobra prawnego. W dogmatyce niemieckiej taką możliwość próbował uzasadnić Andreas Hoyer, który wprowadził pojęcia przestępstw zdatności w rozumieniu formalnym (posiadających expressis verbis klauzulę zdatności w ramach opisu ustawowego stan faktycznego) oraz $\mathrm{w}$ rozumieniu materialnym, w ramach których znamię zdatności jest wprowadzane do opisu typu czynu zabronionego za pośrednictwem wykładni prawa (Hoyer 1987, 16, 29-30, 197-198). Podstawowym warunkiem, jaki przyjął autor w celu zachowania językowych granic wykładni prawa, jest konieczność jednolitego rozumienia znamienia zdatności (Hoyer 1987, 18). Niemniej analiza przeprowadzana przez niemieckiego dogmatyka spotkała się z krytyką pozostałej doktryny prawa karnego. Niezależnie od tej oceny należy zwrócić uwagę, że uwzględnienie zarówno braku niebezpieczeństwa, jak i tolerowanego ryzyka zaburza jednolite pojmowanie znamienia zdatności, ponieważ narusza strukturę ontologiczną pojęcia zdatności, a mianowicie czym innym jest brak związku kauzalnego (brak prawdopodobieństwa) pomiędzy stanem rzeczy wyjścia a stanem rzeczy odniesienia, a czym innym jest tolerowane prawdopodobieństwo zaistnienia negatywnych zdarzeń (tolerowane prawdopodobieństwo).

Z perspektywy granic językowych wykładni założenie Elżbiety Hryniewicz i Jacka Giezka jest zatem nie do zaakceptowania. Niemniej nie oznacza to definitywnego braku podstaw dla przyjęcia kierunku obranego przez Elżbietę Hryniewicz i Jacka Giezka, ponieważ odwołując się do braku niebezpieczeństwa siłą teoretycznej rzeczy można posłużyć się konstrukcją znamienia zdatności, jeżeli chodzi o kluczową z perspektywy stosowania prawa karnego funkcję dowodową znamion przestępstwa. Chodzi zatem o problem epistemologiczny, a więc o to, w jaki sposób należy ustalić, że in concreto w sprawie brak niebezpieczeństwa dla dobra prawnego. Z perspektywy teoretyczno-prawnej takie przeskakiwanie od obowiązywania normy do stosowania normy, od problemów normatywnych czy ontologicznych prawa do problemów epistemologicznych, jest oczywiście nieodpowiednie, ale jak już była mowa, chodzi o dogmatyczne podejście do problematyki ,przeciwdowodu" i jej relacji do normy prawnokarnej.

Zarówno Jacek Giezek, jak i Elżbieta Hryniewicz wyraźnie dostrzegli, że nie wszystkie przestępstwa abstrakcyjnego narażenia posiadają expressis verbis klauzulę zdatności. $Z$ drugiej strony na mocy przyjętych przez nich założeń teoretycznych zdatność do zagrożenia/naruszenia dóbr prawnych jest konieczną przesłanką odpowiedzialności karnej. Jacek Giezek rozwiązuje problem braku znamienia zdatności $\mathrm{w}$ rozumieniu znamienia pozytywnego $\mathrm{w}$ ten sposób, że 
dopuszcza przeciwdowód wskazujący na prawnokarną irrelewantność zachowania, które tylko formalnie wypełniają znamiona czynu zabronionego, ale nie są zdatne do zagrożenia/naruszenia dobra prawnego (por. Giezek 2002: 133). Skoro, jak przyjmuje Jacek Giezek, przedmiotem oceny w ramach przeciwdowodu braku zagrożenia jest zawsze zachowanie, co wynika z tego, że chodzi o przestępstwa abstrakcyjnego narażenia ${ }^{23}$, to znamię zdatności stanowi cechę zachowania (Giezek 2002, 133), a tym samym cechę czynu zabronionego. Ponadto należy zwrócić uwagę, że samo pojęcie zdatności wcale nie przesądza wyłącznie o tym, że znamię zdatności należy relatywizować do zachowania. W szczególności dlatego, że po pierwsze zgodnie z ogólną definicją zdatności jest nią związek pomiędzy stanem rzeczy - wyjścia a stanem rzeczy - następstwa, po drugie struktura znamienia zdatności nie sprowadza się wyłącznie do cechy „zachowania”, ale również wymaga zaistnienia określonych elementów otoczenia ontologicznego określonego zachowania, aby można było ustalić możliwość zaistnienia negatywnych następstw. Należy zwrócić także uwagę na to, że usytuowanie znamienia zdatności w odniesieniu do czynu zabronionego jest w ujęciu Jacka Giezka podyktowane także tym, że w ramach legitymacji przestępstw abstrakcyjnego narażenia przyjmuje on teorię generalnego niebezpieczeństwa (Giezek 2002, 117-118 i 133). Nadal jednak wątpliwości budzi to, w jaki sposób ,przeciwdowód braku zagrożenia” przekłada się na strukturę normy prawnej: zakres jej normowania czy stosowania. Wydaje się, że skoro Jacek Giezek wykorzystał teorię generalnego niebezpieczeństwa - pojęcia klasy czynów z natury niebezpiecznych - do odgraniczenia zachowań prawnokarnie relewantnych od irrelewantnych, a w celu uzyskania tego rozróżnienia wprowadza przeciwdowód braku zagrożenia, to wydaje się, że chodzi o zakres normowania, a więc używając terminologii Jana Woleńskiego, stan faktyczny - braku zagrożenia dla dobra prawnego - nie należy do klasy sytuacji normujących (zakazujących) zachowanie.

\section{PRZECIWDOWÓD BRAKU ZAGROŻENIA W STRUKTURZE PRZESTĘPSTWA}

Przekładając to, co zostało przedstawione, na dogmatyczną strukturę przestępstwa, można wskazać na podział znamion typu czynu zabronionego na znamiona w węższym ${ }^{24}$ - tj. znamiona karalności czynu i szerszym znaczeniu ${ }^{25}-\mathrm{tj}$.

${ }^{23}$ Co do zasady odpowiadające strukturze przestępstwa formalnego.

${ }^{24}$ Zawiera ,te znamiona, które nadają poszczególnym deliktom wyodrębniające je cechy i charakteryzują typową dla tego deliktu treść bezprawia" (Dębski 2013, 375). Zatem węższy zespół znamion odnosi się do charakterystyki czynu zabronionego, dla którego przewidziana jest sankcja. $\mathrm{Z}$ tego względu można za Ryszardem Dębskim stwierdzić, że chodzi o ustawowy stan faktyczny określony w przepisie części szczególnej, z którym związana jest typowa bezprawność (tamże, 387).

${ }^{25}$ Stanowi ,zbiór wszystkich warunków karalności, obejmując zarówno węższy zespół znamion [...], jak i bezprawność, winę oraz obiektywne warunki karalności” (Dębski 2013, 375). 
znamiona bezprawności czynu (Dębski 2013, 375-376). Przyjmując wskaźnikową rolę znamion karalności ${ }^{26}$ w ustalaniu treści bezprawności (zob. Dębski 2013, 389-391), można w jasny sposób uzasadnić powiązanie przeciwdowodu z obowiązywaniem normy prawnokarnej. Przeciwdowód braku zagrożenia odnoszący się do obowiązywania normy prawnokarnej stanowiłby znamię, które dookreśla w sposób negatywny zakres obowiązywania, a więc należałby do zespołu znamion w szerszym rozumieniu. Innymi słowy, analiza opisu znamion czynu w sensie węższym umożliwiająca przyporządkowanie typu czynu do przestępstw zdatności wskazuje, że nie jest bezprawne zachowanie, które nie jest zdatne do naruszenia/narażenia dobra prawnego. Z tego względu znamię zdatności do naruszenia/ narażenia dobra prawnego przy przestępstwach zdatności w sensie materialnym należałoby uznać za znamię bezprawności czynu, tj. naruszającego reguły postępowania $\mathrm{z}$ dobrem prawnym.

Podobnie jak Jacek Giezek zagadnienie to przedstawia Elżbieta Hryniewicz, która wiąże przeciwdowód braku zagrożenia z ryzykownością zachowania i stwierdza wprost, że wykluczenie zdatności do zagrożenia/naruszenia dobra prawnego stanowi okoliczność braku czynu zabronionego (Hryniewicz 2012, 146). Można powiedzieć, że to zagrożenie dla dobra prawnego legitymuje czyn zabroniony (por. Hryniewicz 2012, 146, 238-242 i 280), a dopiero ten czyn może uzasadniać karę.

Odpowiedź na podstawowe pytanie, w jaki sposób „przeciwdowód” może być uwzględniony w strukturze normy prawnokarnej, wydaje się być następująca. Przeciwdowód braku zagrożenia należy uwzględnić na etapie wykładni prawa lub na etapie stosowania prawa. Skuteczne przeprowadzenie przeciwdowodu oznacza, że norma prawnokarna nie jest stosowana dla konkretnego przypadku. Tym samym zagadnienie legitymacji prawa karnego w ujęciu Elżbiety Hryniewicz jest przesunięte na płaszczyznę stosowania prawa, a nie jego normowania. Jest to zresztą klasyczne założenie prawa karnego, które przyjmuje, że podstawową normą prawnokarną nie jest norma prawna normująca określone zachowania ( $\mathrm{tj}$.

${ }^{26} \mathrm{~W}$ polskiej nauce prawa karnego za wskaźnikową rolą znamion karalności w ustaleniu bezprawności opowiada się wyraźnie Ryszard Dębski (Dębski 2013, 387 i 389-390), który jednak podkreśla, że w polskiej dogmatyce prawa karnego nie wprowadza się rozróżnienia między ustaleniem znamion karalności jako odrębnego od bezprawności stopnia wartościowania i ustaleniem znamion karalności jako wstępnego kryterium badania bezprawności (tamże, 390). Wydaje się jednak, że Michałowi Królikowskiemu można przypisać drugi z wymienionych poglądów, ponieważ bezprawność kryminalna jest wyznaczana przez normy sankcjonowane i sankcjonujące w kontekście typu czynu zabronionego i brak kontratypu. Tym samym to zespół znamion ustawowo składających się na istotę czynu stanowi pierwszy etap badania bezprawności, ponieważ to on wyznacza ustawowy stan faktyczny podlegający ocenie pod kątem a) naruszenia normy sankcjonowanej i b) karalności, np. klauzule niepodlegania karze (por. Królikowski 2010, 19). Niemniej autor wyraźnie wskazał, że „normy - sankcjonowana, wyznaczająca zakres dozwolonego zachowania, oraz sankcjonująca, ustalająca zakres karalności za naruszenie normy sankcjonowanej - stanowią oddzielne grupy zagadnień" (tamże, 17). 
norma sankcjonowana), ale norma sankcjonująca, tj. wprowadzająca odpowiedzialność karną. Autorka ta rozumie odniesienie przeciwdowodu braku zagrożenia do normy prawnej w ten sposób, że po pierwsze w drodze wykładni językowej i funkcjonalnej uzyskuje się ,treść normy zawężonej do przypadków, w których zachowanie sprawcy sprzeczne z tą normą narusza przedmiot ochrony danej regulacji lub zagraża mu" (Hryniewicz 2012, 253), po drugie w ramach stosowania prawa weryfikuje się stan faktyczny pod kątem realizacji znamion czynu zabronionego, w tym „wpływu zachowania sprawcy na przedmiot ochrony”, a ostatecznie o odpowiedzialności karnej mowa wyłącznie wówczas, gdy zachowanie co najmniej zagraża dobrom prawnym (tamże, 254).

Z kolei wydaje się, że Jacek Giezek, który wyraźnie stwierdza, że w ramach przeciwdowodu chodzi o zakres obowiązywania normy, sytuuje wskazaną konstrukcję prawniczą na etapie wykładni prawa. Uwzględnienie przeciwdowodu umożliwia zawężenie treści normy prawnokarnej stanowiącej podstawę dla oceny stanu faktycznego pod kątem realizacji znamion przestępstwa, doprowadzając finalnie do uznania badanego stanu faktycznego za prawnokarnie irrelewantny. Z tego powodu można uznać, że uwzględnienie przeciwdowodu jest elementem decyzji walidacyjnej ustalającej obowiązywanie i znaczenie normy: nie jest zakazane (element obowiązywania) zachowanie niebędące niebezpiecznym dla dobra prawnego lub mieszczące się w tolerowanym ryzyku podjętego zachowania (element znaczenia). Natomiast Elżbieta Hryniewicz sprowadza przeciwdowód braku zagrożenia na płaszczyznę stosowania prawa karnego, a na etapie wykładni zwraca się jedynie ku stwierdzeniu, że odkodowanie przedmiotu ochrony jest koniecznym elementem interpretacji prawa (Hryniewicz 2012, 232-250) ${ }^{27}$. Jak stwierdza ,jeżeli zatem w konkretnej sytuacji, na etapie stosowania prawa, mimo formalnej zgodności zachowania sprawcy z dyspozycją normy, można wykluczyć istnienie zagrożenia przedmiotu ochrony, należy przyjąć, że zachowanie sprawcy nie wypełnia ustawowych znamion czynu zabronionego" (tamże, 254). Wydaje się zatem, że przeciwdowód braku zagrożenia jest według Elżbiety Hryniewicz elementem decyzji interpretacyjnej, która wyznacza zakres zastosowania normy prawnokarnej (normy sankcjonowanej) ${ }^{28}$ (tamże, 321-322). Wynika to z tego, że

${ }^{27}$ „Wykładnia funkcjonalna współtworzy [...], a nie tylko koryguje, rezultat wykładni językowej i systemowej" (Hryniewicz 2012, 233).

${ }^{28}$ Przyjęcie przez autorkę, iż chodzi o normę sankcjonowaną, nie wydaje się właściwym rozwiązaniem, choć wynika to z przyjęcia poglądów Łukasza Pohla w zakresie konstrukcji norm sprzężonych w prawie karnym (zob. Pohl 2007, 58-61; por. Hryniewicz 2012, 227-230). Stosowanie prawa karnego odnosi się zawsze do stosowania normy sankcjonującej funkcjonalnie sprzężonej z przekroczeniem normy sankcjonowanej. W postępowaniu karnym, które służy realizacji dyspozycji normy sankcjonującej ,podlega karze”, nie czyni się wobec sprawcy zarzutu przekroczenia normy sankcjonowanej, ale przekroczenie tej normy jest warunkiem koniecznym, choć niewystarczającym (Pohl 2007, 101) dla postawienia zarzutu karno-procesowego, który wyraża się w spełnieniu hipotezy normy sankcjonującej. Należy jednak odnotować, że problematyka przełożenia struktury norm sprzężonych na prawnoprocesowe warunki i elementy odpowiedzialności karnej nie była 
w drodze wykładni odkodowuje się jedynie przedmiot ochrony, a znamię zagrożenia dla dobra prawnego stanowi konsekwencję założeń teoretycznych odnośnie do ratio legis odpowiedzialności karnej (tamże, 281) i opiera się na domniemaniu, że czyn zabroniony stwarza zagrożenie dla dobra prawnego. Przeciwdowód braku zagrożenia jest zatem konstrukcyjnie przeniesiony na etap stosowania prawa (decyzja interpretujacca stan faktyczny w zakresie zastosowania normy prawnokarnej), w którym ocenia się stan faktyczny pod kątem realizacji zagrożenia dla przedmiotu ochrony, tj. czy doszło do naruszenia reguł ostrożności w wyniku realizacji pozostałych znamion strony przedmiotowej (Hryniewicz 2012, 322). Natomiast w interpretacji Jacka Giezka przeciwdowód braku zagrożenia stanowi element wykładni, która zawęża klasę sytuacji normowanych przez typ rodzajowy przestępstwa abstrakcyjnego narażenia do tych, które in concreto zagrażają dobru prawnemu, choćby tylko potencjalnie narażając (decyzja walidacyjna) ${ }^{29}$. Dopiero następnie z uwagi na ocenę stanu faktycznego można za nie pociagnąć do odpowiedzialności karnej (decyzja interpretacyjna) z uwagi na to, że zachowanie nie jest normowane przez dyspozycję ( $\mathrm{tj}$. zakres normowania) normy prawnokarnej (por. Giezek 2002, 133$)^{30}$.

dotąd podejmowana w doktrynie prawa karnego materialnego i procesowego. $Z$ tego względu nie można zgodzić się z Elżbietą Hryniewicz, że z naruszenia normy sankcjonowanej można „zrobić sprawcy zarzut w toku postępowania karnego" (Hryniewicz 2012, 228). W istocie brak przekroczenia normy sankcjonowanej ,,pierwotnie legalne zachowanie” stanowi warunek negatywny możliwości postawienia zarzutu w toku postępowania karnego, ponieważ zachowanie nie jest bezprawne, tj. jest legalne, stąd nie ma znaczenia, czy „formalnie” spełnia hipotezę normy sankcjonującej, gdyż nie ma podstaw dla jej zastosowania (dyspozycja normy), stąd organ prowadzący postępowanie przygotowawcze nie może postawić zarzutu, który stanowi zastosowanie normy sankcjonującej. Ponadto autorka raz wyraźnie podkreśla, że weryfikacja zagrożenia dla dobra prawnego stanowi przesłankę karalności (Hryniewicz 2012, 281), co z perspektywy norm sprzężonych odpowiada normie sankcjonującej, aby ostatecznie stwierdzić, że wskazana weryfikacja przynależy do normy sankcjonowanej (Hryniewicz 2012, 322), co odpowiada bezprawności.

${ }^{29}$ Wydaje się, że z punktu widzenia teoretycznoprawnego można określić taką decyzję walidacyjną jako rozstrzygnięcie negatywne o charakterze niederogacyjnym (zob. Grabowski 2009, 505), gdyż w istocie chodzi o to, iż stosując argumenty formalno-dogmatyczne, teoretyczno-prawne i praktyczne, uznaje się nie tyle, że norma prawna o określonej treści nie obowiązuje, ile to, że norma o zawężonej treści przez uwzględnienie przeciwdowodu braku zagrożenia jest obowiązującym prawem (por. Grabowski 2009, 499), który to następnie jest stosowany do określonego stanu faktycznego, w efekcie którego otrzymuje się decyzję interpretacyjną o strukturze reguły rozstrzygania o odpowiedzialności karnej. Zwłaszcza tak przedstawiony sposób rozumienia decyzji walidacyjnej wydaje się zgodny z koncepcją systemowego obowiązywania norm Jerzego Wróblewskiego, który wskazał, że jednym z warunków obowiązywania jest niesprzeczność normy $\mathrm{N}$ z innymi normami obowiązującymi w systemie prawnym LS. Jeżeli norma N jest sprzeczna, wówczas należy ją zinterpretować w taki sposób, aby w swym znaczeniu nie była sprzeczna z innymi normami obowiązującymi w LS (zob. Wróblewski 2015, 254 i 261-263; por. także Wróblewski 1983, 46-48, 59-62, 80-84 i 91).

${ }^{30} \mathrm{~W}$ ujęciu norm sprzężonych wydaje się, że musi chodzić o normę sankcjonowaną, ponieważ z zakresu jej normowania pozwala ona oddzielić zachowania prawnie irrelewantne „,pierwotna legalność” od zachowań prawnokarnie relewantnych „,bezprawność” lub prawnokarnie 


\section{PODSUMOWANIE}

Z toku wywodu wyłaniają się następujące konkluzje. Po pierwsze, należy odróżnić pojęcie teoretyczne ryzyka od pojęcia dogmatycznego zachowanie ryzykowne. Po drugie, przedmiot ochrony powinien być interpretowany w kontekście relacji ustawowego zespołu znamion czynu zabronionego do dobra prawnego. Po trzecie, jedną z dogmatycznych konstrukcji umożliwiających prawne uzasadnienie dopuszczalności przeciwdowodu jest tzw. znamię zdatności, choć możliwość jego rozszerzenia na wszystkie przestępstwa abstrakcyjnego narażenia na niebezpieczeństwo budzi wątpliwości co do przekroczenia językowych granic wykładni prawa. Po czwarte, przeciwdowód braku zagrożenia w odniesieniu do konstrukcji normy prawnej odnosi się do obowiązywania normy prawnokarnej, co może być interpretowane jako zakres zastosowania lub zakres normowania normy. Przeciwdowód braku zagrożenia, pomimo licznych wątpliwości natury teoretycznej, stricte dogmatycznej oraz pragmatycznej, wydaje się obiecującą figurą umożliwiającą zachowanie ultima ratio prawa karnego opartego na zasadzie ochrony dobra prawnego tam, gdzie z innych przyczyn bezpośrednia interwencja ustawodawcy jest niemożliwa lub znacząco utrudniona, a więc aby nie popadać w zbędną kazuistykę regulacji prawnej, należałoby dopuścić stosowanie przeciwdowodu braku zagrożenia. Niezależnie jednak od tego z perspektywy pozytywistycznie nastawionej większości dogmatyki prawa należy postulować przekształcanie przestępstw „,czystego” abstrakcyjnego narażenia w przestępstwa zdatności albo wprowadzenia ogólnej klauzuli do części ogólnej kodeksu karnego, która jednoznacznie przesądzałaby o dopuszczalności przeciwdowodu braku zagrożenia. Proponowana treść przepisu mogłaby być następująca: ,przeciwdowód braku zagrożenia dla dobra prawnego nie jest wykluczony".

\section{BIBLIOGRAFIA}

Baroke, Urs. 2011. „Grenzenlos Vorverlagerung des Strafrechtsschutzes durch Gefährdungsdelikte". W Grenzen der Vorverlagerung in einem Tatstrafrecht. Eine rechtsvergleichende Analyse am Beispiel des deutschen und ungarischen Strafrechts. Hrsg. Walter Gropp, Arndt Sinn, Ferenz Nagy. Göttingen: Vandenhoeck \& Ruprecht.

Brehm, Wolfgang. 1973. Zur Dogmatik des abstrakten Gefährdungsdelikts. Tübingen: Mohr.

Buttler, Ilona. 2014. Polityka prewencyjna wobec nietrzeźwych kierowców w Polsce w latach 2006-2013 (raport). Warszawa.

Dębski, Ryszard (red.). 2013. System prawa karnego. Nauka o przestępstwie. Warszawa: C.H. Beck.

Dębski, Ryszard. 1995. Pozaustawowe znamiona przestępstwa. O ustawowym charakterze norm prawa karnego i znamionach typu czynu zabronionego nieokreślonych $w$ ustawie. Łódź: Wydawnictwo Uniwersytetu Łódzkiego.

Filipczak, Mateusz. 2014. „Przedpole zagrożenia dla dobra prawnego a opis czynu z art. 178a $\S 1$ k.k.”. Państwo i Prawo 7.

irrelewantnych „wtórna legalność”. 
Giezek, Jacek, Piotr Kardas. 2002. „Sporne problemy przestępstwa działania na szkodę spółki na tle aktualnych wymagań teorii i praktyki”. Palestra 9/10: 7-26.

Giezek, Jacek. 2002. „Narażenie na niebezpieczeństwo oraz jego znaczenie w konstrukcji czynu zabronionego". Przeglad Prawa i Administracji L: 113-134.

Grabowski, Andrzej. 2009. Prawnicze pojęcie obowiazywania prawa stanowionego. Krytyka niepozytywistycznej koncepcji prawa. Kraków: Wydawnictwo Naukowe Uniwersytetu Jagiellońskiego.

Graul, Eva. 1991. Abstrakte Gefährdungsdelikte und Präsumptionen im Strafrecht. Berlin: Duncker \& Humblot.

Greco, Luis. 2011. „Gibt es Kriterien zur Postulierung eines kollektiven Rechtsguts?” W Festschrift für Claus Roxin zum 80. Geburtstag am 15. Mai 2011: Strafrecht als Scientia Universalis. Hrsg. Heinrich Jäger Schünemann. Walter de Gruyter.

Gruszecka, Dagmara. 2012. Ochrona dobra prawnego na przedpolu jego naruszenia: Analiza karnistyczna. Warszawa: Wolters Kluwer.

Hoyer, Andreas. 1987. „Die Eignungsdelikte”. Strafrechtliche Abhandlungen n.F. Bd. 61. Berlin: Duncker \& Humblot.

Hryniewicz, Elżbieta. 2013. „Skutek w prawie karnym”. Prokuratura i Prawo 7-8: 108-126.

Hryniewicz, Elżbieta. 2012. Przestępstwa abstrakcyjnego i konkretnego zagrożenia dóbr prawnych. Warszawa: C.H. Beck.

Królikowski, Michał. 2010. „Okoliczności wyłączające jako konstrukcja sprawiedliwości korygującej”. Czasopismo Prawa Karnego i Nauk Penalnych Rok XIV, 2: 5-24.

Kulesza, Jan. 2014. „Zarys teorii kryminalizacji”. Prokuratura i Prawo 11-12: 87-111.

Matczak, Marcin. 2007. Summa iniuria. O błędzie formalizmu w stosowaniu prawa. Warszawa: Wydawnictwo Naukowe SCHOLAR.

Otto, Hans. 2005. Grundkurs Strafrecht. Die einzelnen Delikte. Berlin: Duncker \& Humblot.

Pohl, Łukasz. 2007. Struktura normy sankcjonowanej. Poznań: Wydawnictwo Naukowe UAM.

Potocka-Banaś, Barbara, Krzysztof Borowiak, Tomasz Janus. 2008. „Alkohol etylowy - wybrane problemy kliniczne i diagnostyczne". Diagnostyka Laboratoryjna 2: 225-230.

Raszeja, Stefan, Władysław Nasiłowski, Jan Markiewicz. 1990. Medycyna sqdowa. Warszawa: PWN.

Schröder, Horst. 1967. „Abstrakt-konkrete Gefährdungsdelikte?” Juristenzeitung 17: 522-525.

Schröder, Horst. 1969. „Die Gefährdungsdelikte im Strafrecht”. Zeitschrift für die gesamte Strafrechtswissenschaft 81: 7-28.

Wohlers, Wolfgang. 2000. Deliktstypen des Präventionsstrafrechts - zur Dogmatik "moderner" Gefährdungsdelikte. Berlin: Duncker \& Humblot.

Wróbel, Włodzimierz. 2009. „Pojęcie «dobra prawnego» w wykładni przepisów prawa karnego”. W Aktualne problemy prawa karnego. Księa pamiqtkowa z okazji Jubileuszu 70. urodzin Profesora Andrzeja J. Szwarca. Red. Łukasz Pohl. Poznań: Wydawnictwo Naukowe UAM.

Wróbel, Włodzimierz. 1993. „Struktura normatywna przepisu prawa karnego”. RPEiS 3: 93-103.

Wróblewski, Jerzy. 1983. Meaning and Truth in Juridical Decision. Wyd. II. Helsinki: A-Tieto Oy.

Wróblewski, Jerzy. 2015. Pisma wybrane. Wybór i wstęp Marek Zirk-Sadowski. Warszawa: Wolters Kluwer.

Zoll, Andrzej. 2011. „Konstytucyjne uzasadnienie kryminalizacji”. W Źródła prawa karnego. Red. Tadeusz Bojarski, Andrzej Marek. Warszawa: Wydawnictwo C.H. Beck; Instytut Nauk Prawnych PAN. 


\title{
Mateusz Filipczak
}

\section{CRIMINAL RESPONSIBILITY AND LACK OF THREAT TO THE LEGAL GOOD IN CRIMES OF ABSTRACT EXPOSURE TO DANGER}

\begin{abstract}
This paper gives some consideration to criminal liability with regard to crimes of abstract exposure to danger. The aim of this discussion is an attempt at justifying a potential restriction on criminal responsibility for this type of crimes by application of a lack of danger to the legal good. The consideration concentrates on a relation between the lack of danger and the legal norm as well as legitimacy of criminal law, a definition of the abstract danger exposure and a legally protected subject with regard to legal interpretation rules.

Keywords: danger, legal good, theory of criminal law, crimes of abstract exposure to danger, interpretation of criminal law, legal norm.
\end{abstract}

